\title{
First report of Iris yellow spot orthotospovirus infecting onion in Santa Catarina State, Brazil
}

\author{
Edivânio Rodrigues de Araújo ${ }^{1} \odot$; Renata Sousa Resende ${ }^{1} \mathbb{0}$; Mirtes Freitas Lima ${ }^{2} \odot$
}

\begin{abstract}
${ }^{1}$ Epagri/Estação Experimental de Ituporanga, Estrada Geral Lageado Águas Negras, 453, CEP: 88400-000, Ituporanga-SC, Brazil. ${ }^{2}$ Embrapa Hortaliças, Rodovia BR-060, Km 09 (Brasília/Anápolis), Fazenda Tamanduá, CEP: 70275-970, Brasília-DF, Brazil.

Autor para correspondência: Edivânio Rodrigues de Araújo (edivanioaraujo@epagri.sc.gov.br)

Data de chegada: 11/12/2020. Aceito para publicação em: 26/03/2021.
\end{abstract}

$10.1590 / 0100-5405 / 246504$

Onion (Allium cepa L.) is the third most economically important vegetable crop in Brazil; its planted area was estimated at approximately 48,000 hectares with total production of 1,556,885 tons in 2019 (9). Santa Catarina is the largest national producing state, accounting for 532,000 tons in the $2019 / 20$ crop season (6). Iris yellow spot orthotospovirus (IYSV), genus Orthotospovirus, family Tospoviridae (4), is transmitted by Thrips tabaci L. in a persistent and propagative manner (10). Frankliniella fusca can also transmit IYSV but less efficiently (15). IYSV has been reported in South, Central and North America, Africa, Europe, Asia, and Oceania (2).

In Brazil, the first report of IYSV-like symptoms in onion fields occurred in 1981, in Rio Grande do Sul State, and the causal agent was initially identified as tomato spotted wilt-like virus (5). However, correct identification of the pathogen as IYSV, causing the disease known as "sapeca", was obtained only in 1994, when disease symptoms were observed in onion fields in the sub-middle region of São Francisco River Valley - Pernambuco and Bahia States (12). Since the 1990s, no new reports on the occurrence of IYSV infecting onion fields in the country have been made.

During 2017/18, 2018/19 and 2019/20 crop seasons, sudden leaf blight symptoms were observed in bulb onion crops in open fields in Santa Catarina State (Figure 1A). Eventually, leaves exhibited whitish diamond-shaped spots, characteristic of IYSV-like symptoms (Figure 1B). In turn, yellow or light green diamond-shaped spots, which may or may not have a lighter center, were observed on scape from seed onion crop (Figure 1C). Sample collection was performed considering three crop seasons: 2017/18: 63 leaf samples were collected - 56 from symptomatic onions and seven from weeds showing leaf spots [Bidens pilosa (three samples), Amaranthus sp. (two samples), Raphanus sp. (one sample), and Euphorbia heterophylla (one sample)]; 2018/19: 12 leaf samples were collected - seven from symptomatic and five from asymptomatic onion plants; 2019/20: 30 leaf samples were collected - all from symptomatic onion plants. Samples were evaluated by NCMELISA (Nitrocellulose Membrane-enzyme-linked immunosorbent assay) with polyclonal antibodies raised against the nucleoprotein of IYSV (produced at the National Center for Vegetable Crops Research - CNPH) or using IYSV ImmunoStrips (Agdia Inc., Elkhart, IN) or even by DAS-ELISA (Double Antibody Sandwich enzyme-linked immunosorbent assay), according to the manufacturer's instructions (Agdia Inc., Elkhart, IN). For each serological test, the sample was considered positive, or virus-infected, compared to the reaction of the positive control (NCM-ELISA: formation of precipitate by the action of enzymatic reaction on the BCIP and NBT, resulting in purplish spots; ImmunoStrips: appearance of a dark line in the positive control; DAS-ELISA: absorbance reading of the sample was at least twice the mean absorbance value recorded for the extract of a healthy plant used as negative control).

Out of 105 field samples analyzed, 33 (31.4\%) had a positive signal to IYSV antibodies, compared to the negative and IYSV-positive controls. It is worth pointing out that all IYSV-positive samples were collected from symptomatic onion plants. Besides, no leaf samples obtained from symptomless onion plants or weed species tested positive. IYSV has been detected in six counties in Santa Catarina State (Figure 2). Interestingly, samples collected in all three crop seasons led to similar infection rates. Among IYSV-positive samples, 20 were collected in the 2017/18 crop season (11 from Ituporanga, five from
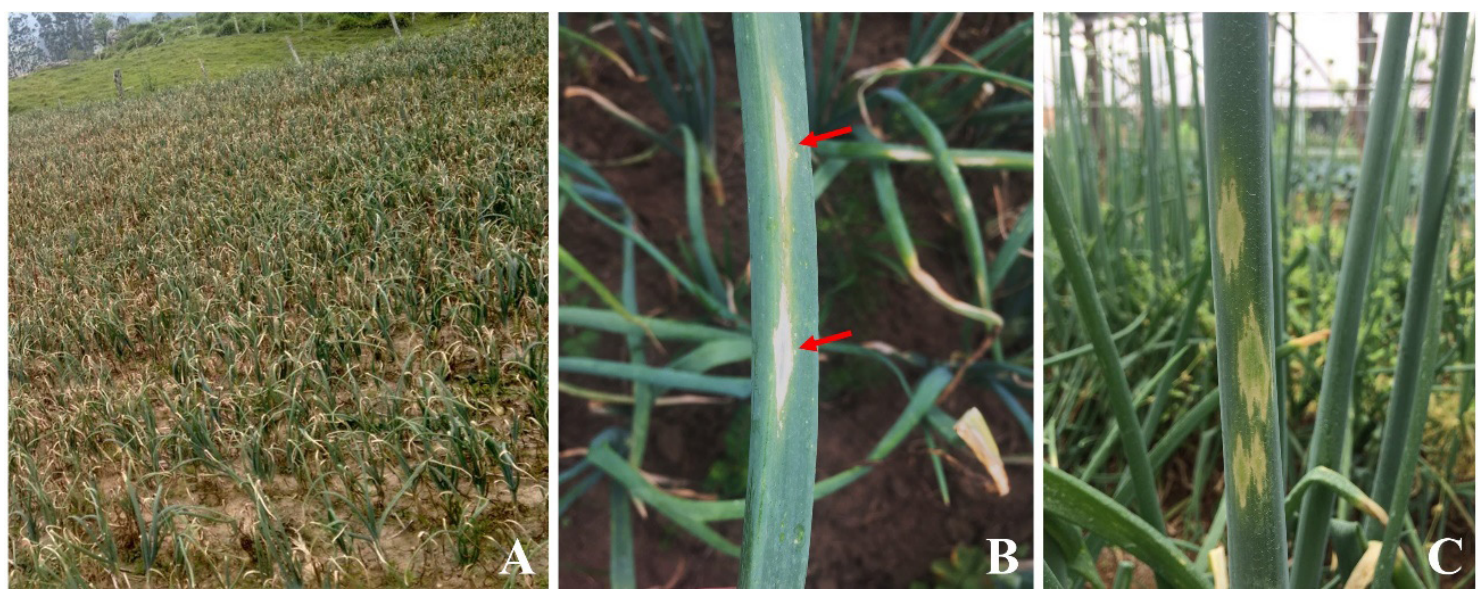

Figure 1. Symptoms of Iris yellow spot orthotospovirus in onion (Allium cepa L.) observed in Santa Catarina State, Brazil. Sudden leaf blight in a bulb onion crop (A); arrows indicate whitish diamond-shaped spots on onion leaves (B); scape showing diagnostic diamond-shaped spots in a seed onion field (C). 


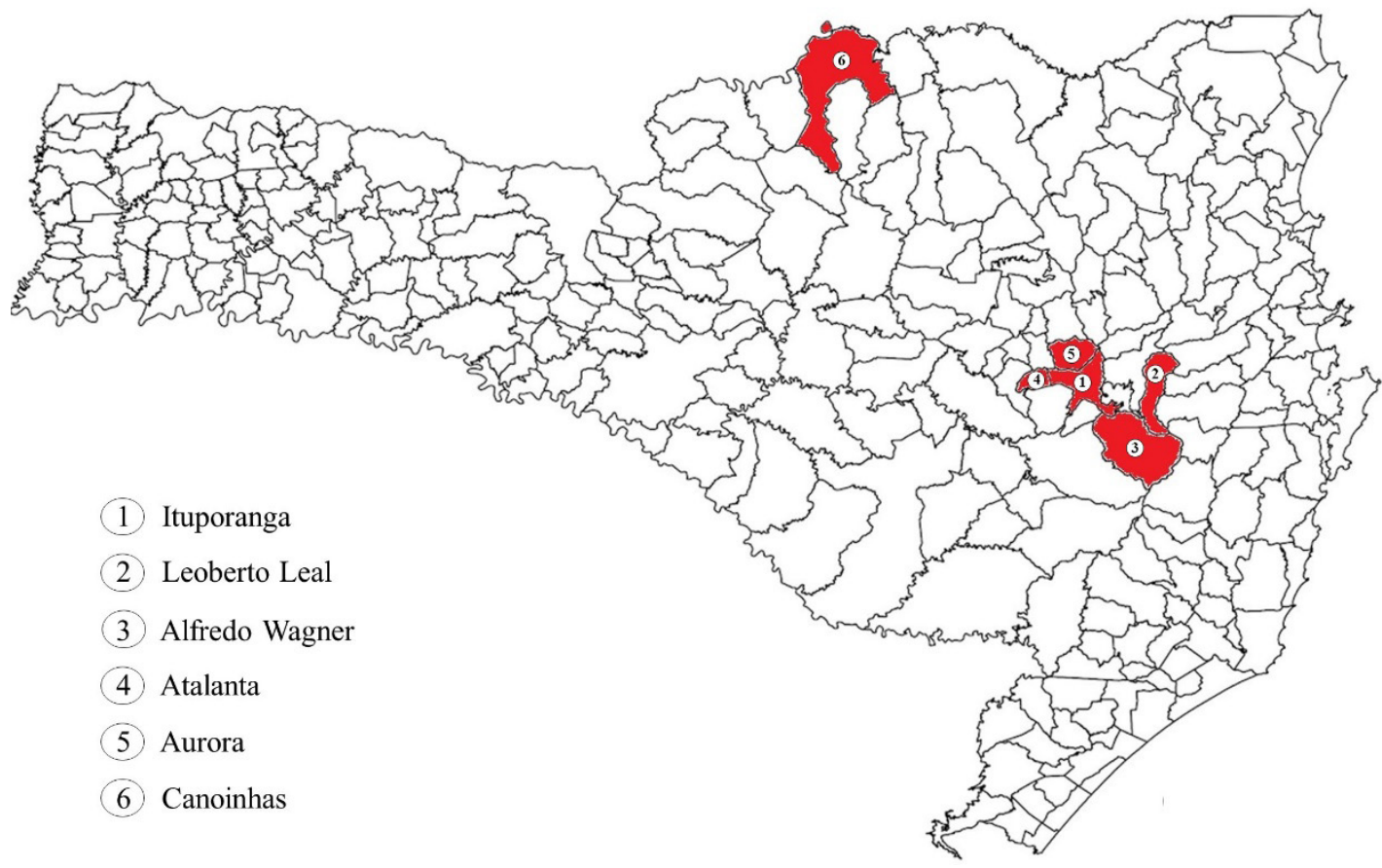

Figure 2. Counties in Santa Catarina State (in red) where Iris yellow spot orthotospovirus has been detected infecting onion (Allium cepa L.) during 2017-2019 crop seasons.

Leoberto Leal, one from Alfredo Wagner, one from Aurora, one from Atalanta, and one from Canoinhas) and showed an infection rate of $31.74 \%$. Leaf samples collected in the 2018/19 crop season also tested positive for IYSV (two from Aurora and two from Ituporanga), resulting in an infection rate of $33.33 \%$. Nine samples from the last crop season $(2019 / 2020)$ also reacted positively with IYSV antibodies (all from Ituporanga County), producing an infection rate of $30.0 \%$.

Considering that the collection of field samples focused on symptomatic plants, the overall detection rate $(31.4 \%)$ can be regarded as relatively low; however, possible justification for symptomatic samples that tested negative to specific IYSV polyclonal antibodies $(68.6 \%)$ are: i) The plants were not infected with IYSV and the observed symptoms were due to other causes, such as abiotic factors, since not all of them had diamond-shaped lesions, a characteristic symptom of this disease. ii) Sampling: differently from other orthotospovirus species, IYSV moves less systemically in the infected plant $(1,11)$ and tends to cause localized infection (14). The virus does not present an even distribution in the infected plant (13), and high virus titers are usually found for inner leaves (10). In addition, the virus may not be found in all leaves. IYSV tends to be localized in and in close proximity to the lesions on leaves and scapes $(2,3)$. It is frequently detected in visible lesions of at least $30-50 \mathrm{~mm}$ (7). Thus, the portion of the leaf sample used for serological analysis could not contain enough viral particles for detection by ELISA, which may eventually result in false negatives (8). iii) The plants could be infected with other viruses and not with IYSV. All positive and negative controls used in the serological tests (NCM-ELISA; DAS-ELISA) reacted as expected.

IYSV may become an emerging virus to onion crops in Brazil as it is in other regions of the world (2). Monitoring onion fields is mandatory to learn about the geographical distribution, spread and occurrence of this disease. To our knowledge, this is the first report of Iris yellow spot orthotospovirus infecting onion in Santa Catarina State.

\section{ACKNOWLEDGEMENTS}

This study was supported by Epagri and CNPq (409509/2018-3).

\section{REFERENCES}

1. Bag, S.; Druffel, K.L.; Salewsky, T.; Pappu, H.R. Nucleotide sequence and genome organization of the medium RNA of Iris yellow spot virus from the United States. Archives of Virology, Wien, v. 154, n. 4, p. 715-718, 2009. DOI: 10.1007/s00705-009-0349-1

2. Bag, S.; Schwartz, H.F.; Cramer, C.S.; Havey, M.J.; Pappu, H.R. Iris yellow spot virus (Tospovirus: Bunyaviridae): From obscurity to research priority. Molecular Plant Pathology, London, v. 16, n. 3, p. 224-237, 2015. DOI: 10.1111/mpp. 12177

3. Boateng, C.O.; Schwartz, H.F. Temporal and localized distribution of Iris yellow spot virus within tissues of infected onion plants. Southwestern Entomologist, McKinney, v. 38, n. 2, p. 183-200, 2013. DOI: https://doi. org/10.3958/059.038.0204

4. Briese, T.; Alkhovsky, S.; Beer, M.; Calisher, C.H.; Charrel, R.; Ebihara, H.; Jain, R.; Kuhn, J.H.; Lambert, A.; Maes, P.; Nunes, M.; Plyusnin, A.; Schmaljohn, C.; Tesh, R.B.; Yeh, S-D.; Elbeaino, T.; Digiaro, M.; Martelli, G.P.; Muehlbach, H-P.; Mielke-Ehret, N.; Sasaya, T.; Choi, I.R.; Haenni, A-L.; Jonson, G.; Shirako, Y.; Wei, T.; Zhou, X.; Junglen, S. (2016) ICTV taxonomic proposal 2016.030avM.A.v6.Bunyavirales. Create the order Bunyavirales, including eight new families, and one renamed family. http://www.ictv.global/proposals-16/2016.030a-vM.A.v6.Bunyavirales.pdf. Accessed on: 01 Oct. 2020.

5. de Ávila, A.C.; Gama, M.I.C.; Kitajima, E.W.; Pereira, W. Um vírus do grupo vira-cabeça do tomateiro isolado de cebola (Allium cepa $\mathrm{L}$.). Fitopatologia Brasileira, Porto Alegre, v. 6, p. 525, 1981.

6. EPAGRI. Números da Agropecuária Catarinense - 2020. Florianópolis, SC, 2020. 64p. (Epagri. Documentos, 313). http://docweb.epagri. sc.gov.br/website_cepa/publicacoes/Numeros_Agropecuaria_Catarinense_maio_2020_site.pdf. Accessed on: 01 Oct. 2020

7. Gent, D. $\bar{H}_{\text {.; }}$ du Toit, L.; Fichtner, S.F.; Krishna Mohan, S.; Pappu, H.R.; Schwartz, H.F. Iris yellow spot virus: an emerging threat to onion bulb and seed production. Plant Disease, St. Paul, v. 90, n. 12, p. 1468-1480, 2006. 
DOI: https://doi.org/10.1094/PD-90-1468

8. Gent, D.H.; Schwartz, H.F.; Khosla, R. Distribution and incidence of Iris yellow spot virus in Colorado and its relation to onion plant population and yield. Plant Disease, St. Paul, v. 88, n. 5, p. 446-452, 2004. DOI: https:// doi.org/10.1094/PDIS.2004.88.5.446

9. IBGE, Sistema IBGE de recuperação automática (SIDRA) (2019). https://sidra.ibge.gov.br/Tabela/1612\#resultado. Accessed on: 10 Nov. 2020.

10. Kritzman, A.; Lampal, M.; Raccah, B.; Gera, A. Distribution and transmission of Iris yellow spot virus. Plant Disease, St. Paul, v. 85, n. 8, p. 838-842, 2001. DOI: https://doi.org/10.1094/PDIS.2001.85.8.838

11. Pappu, H.R.; Jones, R.A.C.; Jain, R.K. Global status of tospovirus epidemics in diverse cropping systems: successes achieved and challenges ahead. Virus Research, Chatham Maritime, v. 141, n. 2, p. 219-236, 2009. DOI: https://doi.org/10.1016/j.virusres.2009.01.009
12. Pozzer, L.; Bezerra, I.C.; Kormelink, R.; Prins, M.; Peters, D.; Resende, R.O.; de Ávila, A.C. Characterization of a tospovirus isolate of Iris yellow spot virus associated with a disease in onion fields in Brazil. Plant Disease, St. Paul, v. 83, n. 4, p. 345-350, 1999. DOI: https://doi.org/10.1094/ PDIS.1999.83.4.345

13. Schwartz, H.F.; Otto, K.; Szostek, S.; Boateng, C.O.; Cranshaw, W.S.; Camper, M.A.; Mahaffey, L. Thrips and IYSV sources in Colorado onion production systems. In: National Allium Research Conference Proceedings, Savannah, pp.44-47, 2008.

14. Smith, T.N.; Jones, R.A.C.; Wylie, S.J. Genetic diversity of the nucleocapsid gene of Iris yellow spot virus. Australasian Plant Pathology, Clayton, v. 35, n. 3, p. 359-362, 2006. DOI: https://doi.org/10.1071/AP06031.

15. Srinivasan, R.; Sundaraj, S.; Pappu, H.R.; Diffie, S.; Riley, D.; Gitaitis, R. Transmission of Iris yellow spot virus by Frankliniella fusca and Thrips tabaci (Thysanoptera: Thripidae). Journal of Economic Entomology, Annapolis, v. 105, n. 1, p. 40-47, 2012. DOI: 10.1603/ec11094 